\title{
EFFECTS OF SUBSTITUTING PALM OLEIN WITH CARBOHYDRATES ON INSULIN SENSITIVITY: A REVIEW
}

\author{
TENG KIM-TIU* and CHANG LIN FAUN*
}

\begin{abstract}
The role of palm olein on insulin resistance, which predisposes to disease progression of type 2 diabetes, is unclear. This article summarises the effects of substituting palm olein with carbohydrates on insulin sensitivity. Two intervention studies have reported conflicting findings. The RISCK (Reading, Imperial, Surreys, Cambridge and King's) study suggested that saturated fat-enriched diet consisting of mainly palm oil and milk fat did not differ from both high and low glycemic carbohydrates on insulin sensitivity in subjects at risk of developing metabolic syndrome. However, another study reported reduced insulin sensitivity after a diet enriched with palm olein and butter compared with high carbohydrate intake. No epidemiological data exists in this context. More clinical trials using solely palm olein in this area are needed. Further well-controlled large scale studies are needed to furnish the information on palm olein replacement with carbohydrates in diabetes prevention.
\end{abstract}

\section{Keywords: palm olein, carbohydrates, insulin sensitivity, dietary fats, saturated fats}

Date received: 21 August 2015; Sent for revision: 24 August 2015; Received in final form: 6 April 2016; Accepted: 3 June 2016.

\section{INTRODUCTION}

The increased consumption of dietary fats is associated with the worldwide epidemic of obesity and related complications (WHO, 2003). Excess fat deposition would cause adiposopathy (adipose tissue dysfunction) which is linked to abnormal increased production of pro-inflammatory cytokines and decreased release of anti-inflammatory adiponectin (Bays et al., 2013). Such phenomenon contributes to the progression of impaired insulin sensitivity, which is one of the clusters of complications leading to the development of type 2 diabetes mellitus (Laakso, 2010). Insulin sensitivity describes the responsiveness of insulin-target cells to insulin. The control of glucose level is initiated with the binding of insulin to insulin receptor which results in tyrosine phosphorylation of insulin receptor (Hirabara et al., 2012). Pro-inflammatory

Malaysian Palm Oil Board,

6 Persiaran Institusi, Bandar Baru Bangi,

43000 Kajang, Selangor, Malaysia.

E-mail: kimtiu@mpob.gov.my mediators accumulated from chronic inflammation due to adiposopathy however suppress insulin signalling through serine phosphorylation, resulting in impaired insulin sensitivity and inhibition of glucose uptake into cells (Olefsky and Glass, 2010).

The rapid growth of fast food restaurants signifies the problems of overconsumption of energy-dense food. Dietary fats have been highlighted in this context due to its higher density of energy content $\left(9 \mathrm{kcal} \mathrm{g}^{-1}\right)$ compared with other macronutrients, i.e. carbohydrates $\left(4 \mathrm{kcal} \mathrm{g}^{-1}\right)$. The Food and Agriculture Organisation (FAO) has recommended reduction of total fat intake, in particular saturated fats in replacement with carbohydrates or monounsaturated fats (FAO, 2010). Numerous scientific reports have put saturated fats as the main dietary culprit to negatively impact health and increase the risk of developing chronic diseases including cardiovascular diseases and type 2 diabetes mellitus (Uusitupa et al., 1994; PérezJiménez et al., 2001; Vessby et al., 2001; Summers et al., 2002; Shah et al., 2007) though there are recent reports suggesting the null effects of saturated fats with the above mentioned diseases (Malhotra, 
2013; Chowdhury et al., 2014; de Souza et al., 2015). This has alleged concerns on the safety of palm oil consumption linking to saturated fat consumption, given that palm oil is the most consumed vegetable oil in the world (Fry and Fitton, 2010).

Palm olein, which is the liquid fraction of palm oil, is widely used as culinary oil worldwide. Palm olein contains $50 \%$ saturated fatty acids ( $45 \%$ palmitic acid and 5\% stearic acid), balanced by another $40 \%$ monounsaturated and 10\% polyunsaturated fatty acids (Yousefi et al., 2013). The versatility and stability of palm olein make it suitable for most of the food formulation. In view of the abundant availability in food products, palm olein has attracted much controversy on the suitability in healthier food reformulation. In the 1980s, palm oil had been urged to be removed from the shelves due to the purported detrimental health effects of tropical oils. Food manufacturers had replaced palm olein with partially hydrogenated vegetable oils, such as partially hydrogenated soyabean oil, which was later found to be containing trans-fatty acids (McNamara, 2010). Extensive research based on concrete evidence derived from human and epidemiological studies suggest the detrimental effects of trans-fatty acids on cardiovascular diseases and related complications. This has lead to regulations set to limit the use of trans-fatty acids in food formulations (McNamara, 2010). Meanwhile, the trend for healthier food formulation has then moved towards formulation of low-fat food products. It was claimed that low-fat food products are healthier due to lower energy content; however the energy content derived from dietary fats has mainly been replaced by carbohydrates, in particular refined carbohydrates.

It has been reported that the consumption of refined carbohydrates may lead to development of type 2 diabetes (Maki and Phillips, 2015). We have estimated that load of carbohydrates in a set meal, i.e. pasta with a glass of coke, or fried rice with a glass of sweetened drink contributes to $>60 \%$ carbohydrates in a meal. High intake of carbohydrates in a single meal has been reported to promote hyperglycemic responses (Blaak et al., 2012). This is particularly detrimental to individuals with insulin resistance who are susceptible to the development of type 2 diabetes. Predicted upon that, our current review is aimed to examine the effects of substituting palm olein with carbohydrates on insulin sensitivity.

\section{PALM OLEIN vs. CARBOHYDRATES ON INSULIN SENSITIVITY}

Data from epidemiological studies on this topic are limited. Results showing that higher intake of saturated fats is associated with insulin resistance are confounded by many factors, i.e. dietary compounds, total amount of dietary fat, body weight, etc. There is no research conducted on the use of solely palm olein, which is a semi-saturated vegetable oil on insulin sensitivity. The information linking saturated fats on this aspect may be limited based on associations between dietary intake and changes in serum or plasma fatty acids with insulin sensitivity or type 2 diabetes (Vessby et al., 1994; 2002; Wang et al., 2003; Riserus, 2008). The association depicted does not show a causal relationship, hence, vigorously well-controlled intervention studies are warranted for further confirmation. In this respect, we summarise the evidence derived from two intervention studies, comparing palm olein as part of a saturated fat-enriched diet with carbohydrates on insulin sensitivity.

\section{Clinical Evidence}

No long-term intervention studies on dietary fats and diabetes are available. Insulin sensitivity, the intermediate marker for disease end-point has been used in dietary assessment. Clinical studies were identified by searching Pubmed, EMBASE, Cochrane databases for the present review. Inclusion criteria were English language articles reporting the measurement of at least one indices of insulin sensitivity and insulin secretion in both postprandial and fasting measurements following the consumption of palm olein-rich meal and carbohydrate-rich meal. Keywords used in the search included 'saturated fat', 'palm', 'carbohydrate', 'low fat', 'insulin sensitivity', 'insulin', 'glucose', 'randomised controlled trial', 'human' and 'clinical trial'. A total of 262 papers were retrieved from the search, only two studies were identified comparing palm olein vs. carbohydrates where both sources of dietary fats were blended with butter fat or dairies (Table 1). RISCK (Reading, Imperial, Surreys, Cambridge and King's) (Jebb et al., 2010), is the largest multi-centre study involving subjects at risk of developing metabolic syndrome. The study was a parallel design, randomised controlled trial comparing high-saturated fat and high glycemic index (HS/HGI), high-monounsaturated fat and high glycemic index (HM/HGI), highmonounsaturated fat and low glycemic index (HM/ LGI), low-fat and high glycemic index (LF/HGI), and low-fat and low glycemic index (LF/LGI) diets in 548 subjects completing 24-week intervention each. The study instructed the free-living subjects to consume daily fat intake at $38 \%$ en where key sources of fat and carbohydrates were provided. Both palm oil and milk fat were used as dietary fat in place of the control (HS) diet while olive oil and high oleic sunflower oil were used as the fat sources of HM diets. The MUFA-enriched diets were 7\% en higher in MUFA content whereas the low-fat 
TABLE 1. SUMMARY OF STUDIES COMPARING PALM OIL $v$ s. CARBOHYDRATE ON INSULIN SENSITIVITY

\begin{tabular}{|c|c|c|c|c|c|c|c|}
\hline Reference & $\begin{array}{l}\text { Health } \\
\text { status; } \\
\text { n (M/W) }\end{array}$ & $\begin{array}{l}\text { Age } \\
\text { (yr) }\end{array}$ & Design & Duration & Treatment & Dietary intervention & Outcomes \\
\hline $\begin{array}{l}\text { Jebb et al. } \\
\text { (2010) }\end{array}$ & $\begin{array}{l}\text { At risk of } \\
\text { metabolic } \\
\text { syndrome; } \\
548 \\
(230 / 318) \\
\text { HS/HGI; } \\
85 \\
\text { HM/HGI; } \\
111 \\
\text { HM/LGI; } \\
116 \\
\text { LF/HGI; } \\
116 \\
\text { LF/LGI; } \\
121\end{array}$ & $\begin{array}{l}M: 52 \pm \\
10 \\
W: 51 \pm \\
9\end{array}$ & $\begin{array}{l}\text { Randomised, } \\
\text { controlled, } \\
\text { parallel, } \\
\text { non-blinded } \\
\text { Intravenous } \\
\text { glucose } \\
\text { tolerance } \\
\text { test ( } 3 \mathrm{hr)} \\
\text { after diet } \\
\text { intervention }\end{array}$ & $\begin{array}{l}6 \text { months } \\
4 \text { weeks } \\
\text { run-in }\end{array}$ & $\begin{array}{l}\text { 1. HS/HGI } \\
\text { 2. HM/HGI } \\
\text { 3. HM/LGI } \\
\text { 4. LF/HGI } \\
\text { 5. LF/LGI }\end{array}$ & 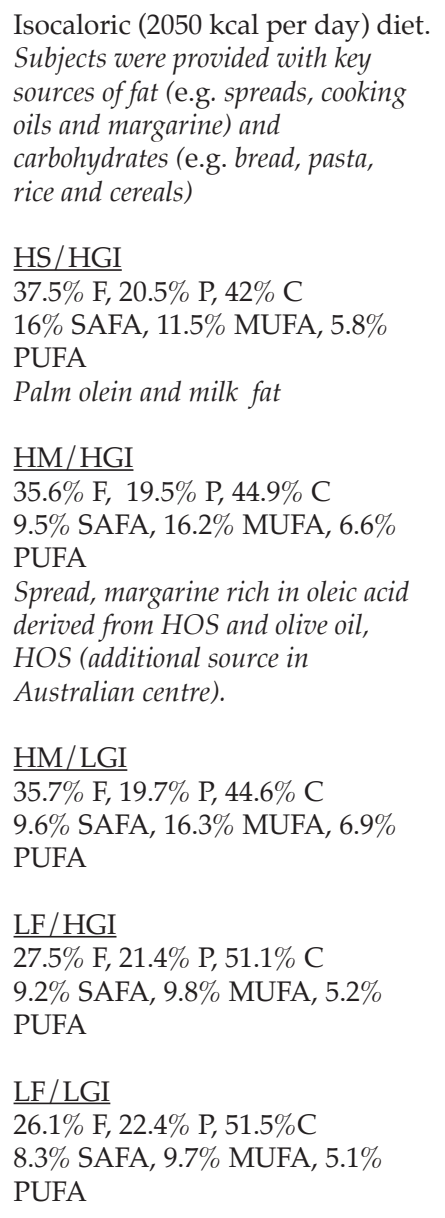 & $\begin{array}{l}\text { Insulin sensitivity, } \\
\text { Sg, }^{\mathrm{AIR}_{\mathrm{G}^{\prime}}} \\
\text { RQUICKI: NS }\end{array}$ \\
\hline $\begin{array}{l}\text { Perez- } \\
\text { Jimenez } \\
\text { et al. }(2001)\end{array}$ & $\begin{array}{l}\text { Healthy; } \\
59(30 / 29)\end{array}$ & $\begin{array}{l}23.1 \pm \\
1.8\end{array}$ & $\begin{array}{l}\text { Randomised, } \\
\text { controlled, } \\
\text { cross-over } \\
\text { Modified } \\
\text { insulin } \\
\text { suppression } \\
\text { test on the } \\
\text { last day of } \\
\text { intervention, } \\
\text { where a } \\
\text { continuous } \\
\text { somatostatin } \\
\text { (to inhibit } \\
\text { endogenous } \\
\text { insulin } \\
\text { secretion), } \\
\text { insulin and } \\
\text { glucose were } \\
\text { infused into } \\
\text { vein. }\end{array}$ & $\begin{array}{l}4 \text { weeks } \\
\text { Bleeding } \\
\text { time } \\
\text { during } \\
\text { insulin } \\
\text { suppression } \\
\text { on test: } \\
\text { 150,160, } \\
170,180 \mathrm{~min}\end{array}$ & $\begin{array}{l}\text { 1. HS } \\
\text { 2. HM } \\
\text { 3. HC } \\
\text { Diet } \\
\text { sequence: } \\
\mathrm{HS} \rightarrow \mathrm{HM} \rightarrow \\
\mathrm{HC} \\
\text { or } \\
\mathrm{HS} \rightarrow \mathrm{HC} \rightarrow \\
\mathrm{HM}\end{array}$ & 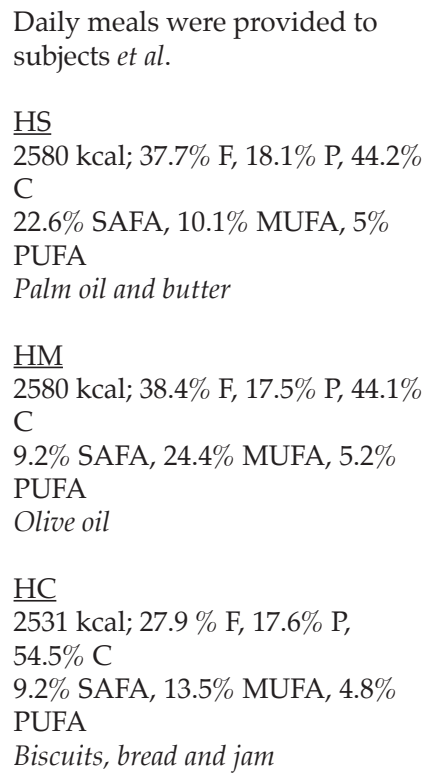 & $\begin{array}{l}\text { Fasting } \\
\text { measurements } \\
\text { Insulin: HS } \uparrow \text { vs. } \\
\text { HM and HC } \\
\text { Glucose: NS } \\
\text { Glucose uptake in } \\
\text { monocyte } \\
\text { Basal glucose } \\
\text { uptake and insulin- } \\
\text { stimulated glucose } \\
\text { uptake: HS } \downarrow \text { vs. } \\
\text { HM and HC } \\
\\
\text { Modified insulin } \\
\text { suppression test } \\
\text { Mean glucose: } \\
\text { HS } \uparrow \text { vs. HM } \\
\text { and HC } \\
\text { Mean insulin: NS }\end{array}$ \\
\hline
\end{tabular}

Note: $\mathrm{n}$ - sample size; M - men; W - women; HS - high-saturated fatty acids; HGI - high glycemic index; HM - high-monounsaturated fatty acids; LGI - low glycemic index; LF - low-fat; y - year; F - fat; P - protein; C - carbohydrate; \%, \% energy; SAFA - saturated fatty acids; MUFA - monounsaturated fatty acids, PUFA - polyunsaturated fatty acids; HOS - high-oleic sunflower oil; Sg - glucose effectiveness; $\mathrm{AIR}_{\mathrm{G}}$ - an indicator of endogenous insulin secretion; RQUICKI - revised quantitative insulin sensitivity check index; NS - no significant difference between diets; HC - high-carbohydrate; AUC - area under the curve; $\uparrow \uparrow$ - significantly higher; vs. - compared to; $\downarrow$ - lower compared to baseline; $\downarrow \downarrow$ - significantly lower; NS - no significant difference between diets. 
diets were enriched with $10 \%$ en carbohydrates, when compared to HS diets. Intravenous glucose tolerance test (IVGTT) was conducted to examine the changes in insulin sensitivity. The method is highly correlated with euglycemic clamp. The study found that isoenergetic replacement of saturated fat with monounsaturated fat or carbohydrates has similar effect on insulin sensitivity, glucose effectiveness and insulin secretion as measured by IVGTT and revised quantitative insulin sensitivity check index (RQUICKI) calculation.

The cross-over design study conducted by Pérez-Jiménez et al. (2001) provided daily meal to 59 young healthy subjects in a four-week randomised controlled trial. The diet intervention started with a four-week saturated fat-enriched diets $(38 \%$ en total fat; $23 \%$ en saturated fats), followed by the randomised allocation of Mediterranean diet (38\% en total fat; $10 \%$ en saturated fats) and carbohydrate diet ( $55 \%$ en carbohydrates; $10 \%$ en saturated fats) for $2 \times 4$ weeks. The fat source for saturated fat diet was a blend of palm olein and butter while olive oil, nuts and grains were emphasised in Mediterranean diet. The additional carbohydrate content in carbohydrate-enriched diet was mainly biscuits, bread and jam. The isocaloric substitution in this study resulted in an improvement of insulin sensitivity following both Mediterranean and carbohydrate diets, as indicated by a decrease in mean plasma glucose concentrations during the insulin suppression test and an increase in both basal and insulin-stimulated 2-deoxiglucose uptake in peripheral monocytes. Saturated fat-enriched diet, however was found to increase both fasting insulin and non-esterified fatty acid concentrations compared with Mediterranean and carbohydrate diets. However, the clinical applications of this study are limited due to a relatively short duration of study intervention and small sample size. In addition, the dietary effect of saturated fat-enriched diet may be confounded by the habitual diet pattern prior to the commencement of dietary intervention because saturated fat-enriched diet was not included in the randomisation of dietary sequence.

\section{CONCLUSION}

No apparent impact by exchanging palm olein with carbohydrates was concluded based on the current limited clinical evidence available. There are no clinical studies using solely palm olein as the dietary fat component for the comparison with carbohydrates, hence, interference from other dietary fat sources, i.e. butter and animal fats, hence, exists. The large scale RISCK study provided promising data on the effect of saturated fats on insulin sensitivity, which provides a platform for clinical outcome study using diabetes as study end- point. The influence of carbohydrates and dietary fats should be put into extensive research to examine the long-term impact on human health and disease risk factors.

\section{ACKNOWLEDGEMENT}

We thank the Director-General of MPOB for permission to publish this article. We also thank Dr Nagendran Bala Sundram for reviewing the manuscript.

\section{REFERENCES}

BAYS, H E; TOTH, P P; KRIS-ETHERTON, P M; ABATE, N; ARONNE, L J; BROWN, W V; GONZALEZ-CAMPOY, J M; JONES, S R; KUMAR, R; LA FORGE, R and SAMUEL, V T (2013). Obesity, adiposity, and dyslipidemia: a consensus statement from the National Lipid Association. J Clin Lipidol, 7: 304-383. http:/ / www.ncbi.nlm.nih. gov / pubmed / 23890517

BLAAK, E E; ANTOINE, J M; BENTON, D; BJORCK, I; BOZZETTO, L; BROUNS, F; DIAMANT, M; DYE, L; HULSHOF, T; HOLST, J J; LAMPORT, D J; LAVILLE, M; LAWTON, C L; MEHEUST, A; NILSON, A; NORMAND, S; RIVELLESE, A A; THEIS, S; TOREKOV, S S and VINOY, S (2012). Impact of postprandial glycaemia on health and prevention of disease. Obes. Rev., 13: 923-984. http: / / www.ncbi.nlm.nih.gov/pubmed/22780564

CHOWDHURY, R; WARNAKULA, S; KUNUTSOR, S; CROWE, F; WARD, H A; JOHNSON, L; FRANCO, $\mathrm{O} \mathrm{H}$; BUTTERWORTH, A S; FOROUHI, N G; THOMPSON, S G; KHAW, K T; MOZAFFARIAN, D; DANESH, J and DI ANGELANTONIO, E (2014). Association of dietary, circulating, and supplement fatty acids with coronary risk: a systematic review and meta-analysis. Ann Intern Med, 160: 398-406. http: / / www.ncbi.nlm.nih.gov/ pubmed/24723079

DE SOUZA, R J; MENTE, A; MAROLEANU, A; COZMA, A I; HA, V; KISHIBE, T; ULERYK, E; BUDYLOWSKI, P; SCHUNEMANN, H; BEYENE, J and ANAND, S S (2015). Intake of saturated and trans unsaturated fatty acids and risk of all cause mortality, cardiovascular disease, and type 2 diabetes: systematic review and meta-analysis of observational studies. BMJ, 351: h3978. http:// www.ncbi.nlm.nih.gov/pubmed/26268692

FAO (2010). Fats and fatty acids in human nutrition. Report of an expert consultation. FAO Food and Nutrition Paper, 91: 1-166. http://www.ncbi.nlm. nih.gov/pubmed / 21812367 
FRY, J and FITTON, C (2010). The importance of the global oils and fats supply and the role that palm oil plays in meeting the demand for oils and fats worldwide. J. Am. Coll. Nutr., 29: 245S-252S. http:/ / dx.doi.org/10.1080/07315724.2010.10719841

HIRABARA, S M; GORJAO, R; VINOLO, M A; RODRIGUES, A C; NACHBAR, R T and CURI, R (2012). Molecular targets related to inflammation and insulin resistance and potential interventions. J Biomed Biotechnol, 2012: 379024. http:/ / www.ncbi. nlm.nih.gov / entrez / query.fcgi?cmd=Retrieve\&db $=$ PubMed\&dopt $=$ Citation\&list_uids $=23049242$

JEBB, S A; LOVEGROVE, J A; GRIFFIN, B A; FROST, G S; MOORE, C S; CHATFIELD, M D; BLUCK, L J; WILLIAMS, C M; SANDERS, T A and GROUP, R S (2010). Effect of changing the amount and type of fat and carbohydrate on insulin sensitivity and cardiovascular risk: the RISCK (Reading, Imperial, Surrey, Cambridge and Kings) trial. Am. J. Clin. Nutr., 92: 748-758. http:/ / www.ncbi.nlm.nih.gov/ pubmed / 20739418

LAAKSO, M (2010). Cardiovascular disease in type 2 diabetes from population to man to mechanisms: the Kelly West Award Lecture 2008. Diabetes Care, 33: 442-449. http://www.ncbi.nlm.nih.gov/ pubmed / 20103560

MALHOTRA, A (2013). Saturated fat is not the major issue. BMJ, 347: f6340. http: / / www.ncbi.nlm. nih.gov/ pubmed/24149521

MAKI, K C and PHILLIPS, A K (2015). Dietary substitutions for refined carbohydrate that show promise for reducing risk of type 2 diabetes in men and women. J. Nutr., 145: 159S-163S. http: / / www. ncbi.nlm.nih.gov/pubmed / 25527674

MCNAMARA, D J (2010). Palm oil and health: a case of manipulated perception and misuse of science. J. Am. Coll. Nutr., 29: 240S-244S. http:/ / www.ncbi. nlm.nih.gov/pubmed / 20823485

OLEFSKY, J M and GLASS, C K (2010). Macrophages, inflammation, and insulin resistance. Annu Rev Physiol, 72: 219-246. http: / / www.ncbi.nlm.nih.gov / pubmed / 20148674

PÉREZ-JIMÉNEZ， F; LÓPEZ-MIRANDA， J; PINILLOS, M D; GÓMEZ, P; PAZ-ROJAS, E; MONTILLA, P; MARÍN, C; VELASCO, M J; BLANCO-MOLINA, A; JIMÉNEZ PEREPÉREZ, J A and ORDOVÁS, J M (2001). A Mediterranean and a high-carbohydrate diet improve glucose metabolism in healthy young persons. Diabetologia, 44: 20382043. http: / / dx.doi.org/10.1007/ s001250100009
RISERUS, U (2008). Fatty acids and insulin sensitivity. Curr. Opin. Clin. Nutr. Metab. Care, 11: 100-105. http: / / www.ncbi.nlm.nih.gov/pubmed/18301083

SHAH, M; ADAMS-HUET, B; BRINKLEY, L; GRUNDY, S M and GARG, A (2007). Lipid, glycemic, and insulin responses to meals rich in saturated, cismonounsaturated, and polyunsaturated (n-3 and n-6) fatty acids in subjects with type 2 diabetes. Diabetes Care, 30: 2993-2998. http:/ / www.ncbi.nlm. nih.gov/pubmed/17804680

SUMMERS, L K; FIELDING, B A; BRADSHAW, H A; ILIC, V; BEYSEN, C; CLARK, M L; MOORE, N R and FRAYN, K N (2002). Substituting dietary saturated fat with polyunsaturated fat changes abdominal fat distribution and improves insulin sensitivity. Diabetologia, 45: 369-377. http://www. ncbi.nlm.nih.gov/pubmed/11914742

UUSITUPA, M; SCHWAB, U; MAKIMATTILA, S; KARHAPAA, P; SARKKINEN, E; MALIRANTA, H; AGREN, J and PENTTILA, I (1994). Effects of two high-fat diets with different fatty acid compositions on glucose and lipid metabolism in healthy young women. Am. J. Clin. Nutr., 59: 1310-1316. http:// www.ncbi.nlm.nih.gov / pubmed / 8198055

VESSBY, B; ARO, A; SKARFORS, E; BERGLUND, L; SALMINEN, I and LITHELL, H (1994). The risk to develop NIDDM is related to the fatty acid composition of the serum cholesterol esters. Diabetes, 43: 1353-1357. http://www.ncbi.nlm.nih. gov/pubmed/7926311

VESSBY, B; GUSTAFSSON, I B; TENGBLAD, S; BOBERG, $M$ and ANDERSSON, A (2002). Desaturation and elongation of fatty acids and insulin action. Ann. N. Y. Acad. Sci., 967: 183-195. http: / / www.ncbi.nlm.nih.gov/ pubmed / 12079847

VESSBY, B; UUSITUPA, M; HERMANSEN, K; RICCARDI, G; RIVELLESE, A A; TAPSELL, L C; NALSEN, C; BERGLUND, L; LOUHERANTA, A; RASMUSSEN, B M; CALVERT, G D; MAFFETONE, A; PEDERSEN, E; GUSTAFSSON, I B; STORLIEN, L H and STUDY, K (2001). Substituting dietary saturated for monounsaturated fat impairs insulin sensitivity in healthy men and women: the KANWU Study. Diabetologia, 44: 312-319. http://www.ncbi. nlm.nih.gov/pubmed/11317662

WANG, L; FOLSOM, A R; ZHENG, Z J; PANKOW, J $S$; ECKFELDT, J H and INVESTIGATORS, AS (2003). Plasma fatty acid composition and incidence of diabetes in middle-aged adults: the atherosclerosis risk in communities (ARIC) study. Am. J. Clin. Nutr., 78: 91-98. http://www.ncbi.nlm.nih.gov/ pubmed / 12816776 
WHO (2003). Diet, nutrition and the prevention of chronic diseases. WHO Technical Report Series, 916: i-viii, 1-149. http://www.ncbi.nlm.nih.gov/ pubmed/12768890
YOUSEFI, M; NATEGHI, L and REZAEE, K (2013). Investigation of physicochemical properties, fatty acids profile and sterol content in Malaysian coconut and palm oil. Ann. Biol. Res., 4: 214-219. http:// scholarsresearchlibrary.com/abr-vol4-iss4.html 